\title{
Survival of Oocysts of Eimeria alabamensis on Pastures under Different Climatic Conditions in Sweden
}

\author{
By C. Svensson
}

Experimental Station, Veterinary Institute, Skara, and Department of Parasitology, National Veterinary Institute and Swedish University of Agricultural Sciences, Uppsala, Sweden.

\begin{abstract}
Svensson, C.: Survival of oocysts of Eimeria alabamensis on pastures under different climatic conditions in Sweden. Acta vet. scand. 1995, 36, 9-20. - The extent to which oocysts of the coccidian parasite Eimeria alabamensis can survive the winter and cause clinical coccidiosis in different parts of Sweden was investigated. Fecal samples were collected between May and July 1993 from calves on 59 farms where calves had grazed the same pasture for at least 5 consecutive years. The farms were situated in 9 regions of Sweden with different climatic conditions in the winter. On each farm, 5 samples of feces were collected from the floor of the calf-house before the calves were turned out in the spring, and again from the pasture on days 4 or 5,8 or 9 and 10 or 11 after they were turned out. Overwintering of oocysts of E. alabamensis was considered to have occurred if an increase in the excretion rate of oocysts of this species could be demonstrated 8 to 11 days after calves had been turned out to pastures that had not been grazed since the previous autumn. Oocysts were shown to have overwintered on 27 farms, representing all 9 regions. Samples from $20(34 \%)$ of the farms representing all the climatic regions contained more than 850000 oocysts per $g$ of feces. This was comparable with the numbers found in animals with clinical coccidiosis due to E. alabamensis. Delaying turnout until the beginning of July did not affect the infection rate of the calves. However, calves which were turned out to pastures that had been grazed by older cattle or horses, either earlier in the spring or in previous years, excreted significantly fewer oocysts than calves which were turned out to pastures that had been grazed only by calves. A questionnaire answered by 321 dairy farmers revealed that of the 298 farmers who turned their first-season grazing cattle out to traditional pastures, $179(60 \%)$ had used the same pasture for at least 5 years. These 179 farmers had experienced a significantly higher incidence of diarrhoea in their calves during the first 2 weeks at pasture than those farmers who had used different pastures.
\end{abstract}

coccidiosis; protozoal infection; diarrhoea.

\section{Introduction}

The coccidian parasite Eimeria alabamensis has generally been considered non-pathogenic under field conditions (Levine 1985). However, during the last decade there have been reports of its role in clinical coccidiosis in young grazing cattle in north east Germany
(Gräfner et al. 1982, 1985), and the species has recently been recognised as a cause of diarrhoea in Swedish calves shortly after they had been turned out to graze in the spring (Svensson et al. 1994).

Svensson et al. (1994) showed that overwintered oocysts on pasture was the main source 

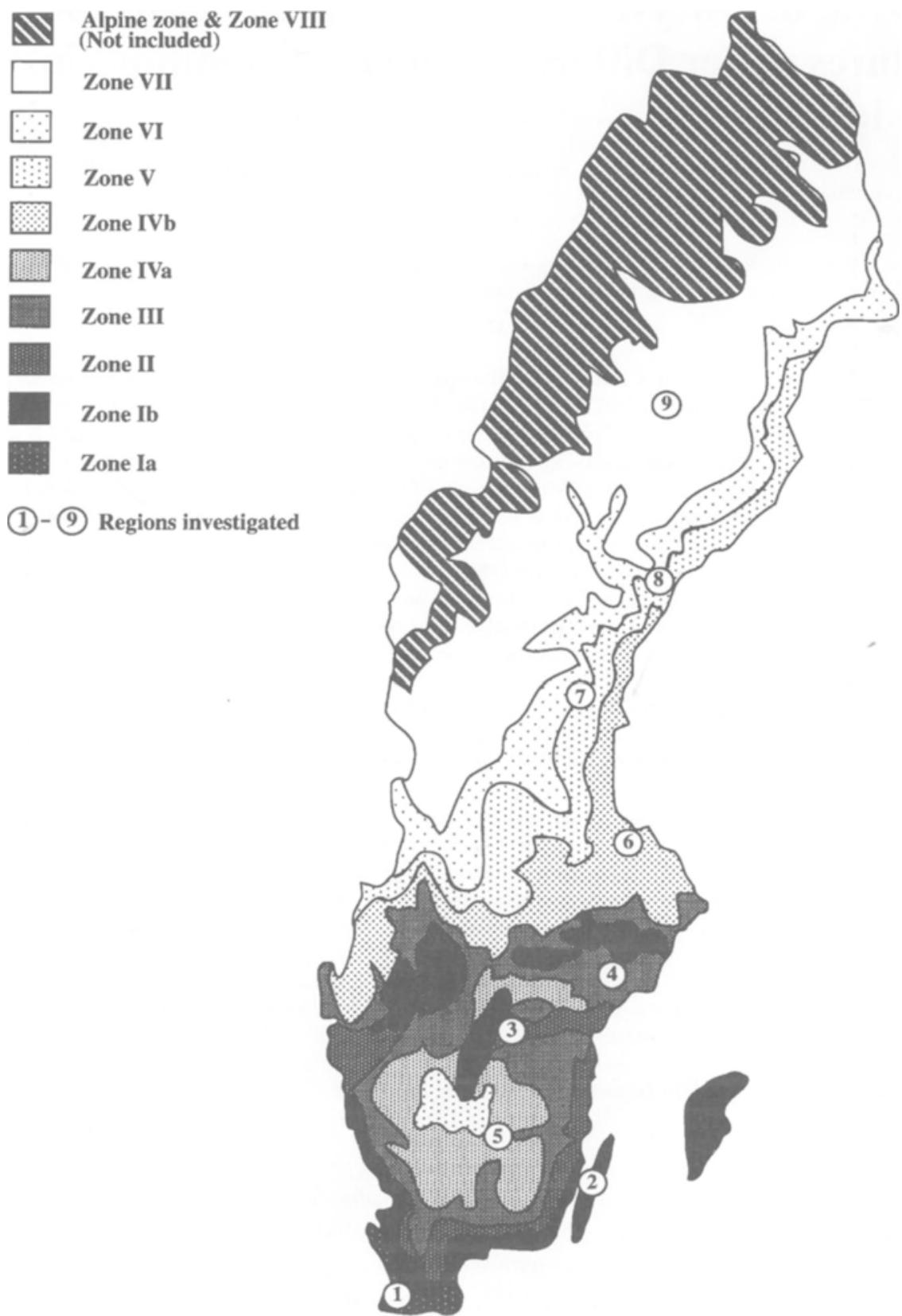

Figure 1. The 9 regions investigated in the study plotted on a climatic zone map of Sweden (modified after the Swedish Society for Horticulture). 


\section{Pasture used for first-grazing calves}

a Field changed every or every second year.

ㅁ Same field used for 3-4 years.

$\square \quad$ Same field used for 5-10 years.

$\square \quad$ Same field used for more than $\mathbf{1 0}$ years.

\section{Diarrhoea in first-grazing calves during the first} two weeks on grass occurs

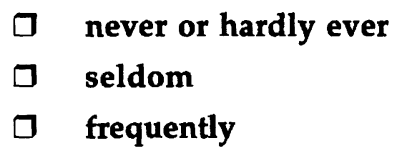

3. Size of herd: No. of dairy cows .......

4. Each year about ............... calves are sent to pasture.

Figure 2. The questionnaire form sent out to 450 dairy farmers. (In translation.)

of infection to grazing calves under Swedish conditions. The calves became infected during their very first days on grass and developed clinical coccidiosis with gruel-like or watery diarrhoea 4 to 6 days after having been turned out. Their appetite decreased, their condition deteriorated, and large numbers of oocysts of E. alabamensis were excreted 8 to 10 days after turnout.

In experimental infections, large numbers of oocysts are not excreted until 8 days after the inoculation (Davis et al. 1955, Soekardono et al. 1975, Hooshmand-Rad et al. 1994). At $25^{\circ} \mathrm{C}$ the oocysts take 5 to 8 days to sporulate, i.e. to become infective, but at $15^{\circ} \mathrm{C}$ no significant development was observed after 12 days (Soekardono et al. 1975). As a result, any oocysts shed by the calves during their first few days at pasture could not be the source of the oocysts of $E$. alabamensis excreted 8 to 10 days after turnout. Furthermore, experimental studies have shown that the oocysts ingested by the calves before they are turned out are not the source of the large numbers of oocysts excreted 8 to 10 days after turnout (Svensson et al. 1994). It can therefore be con- 

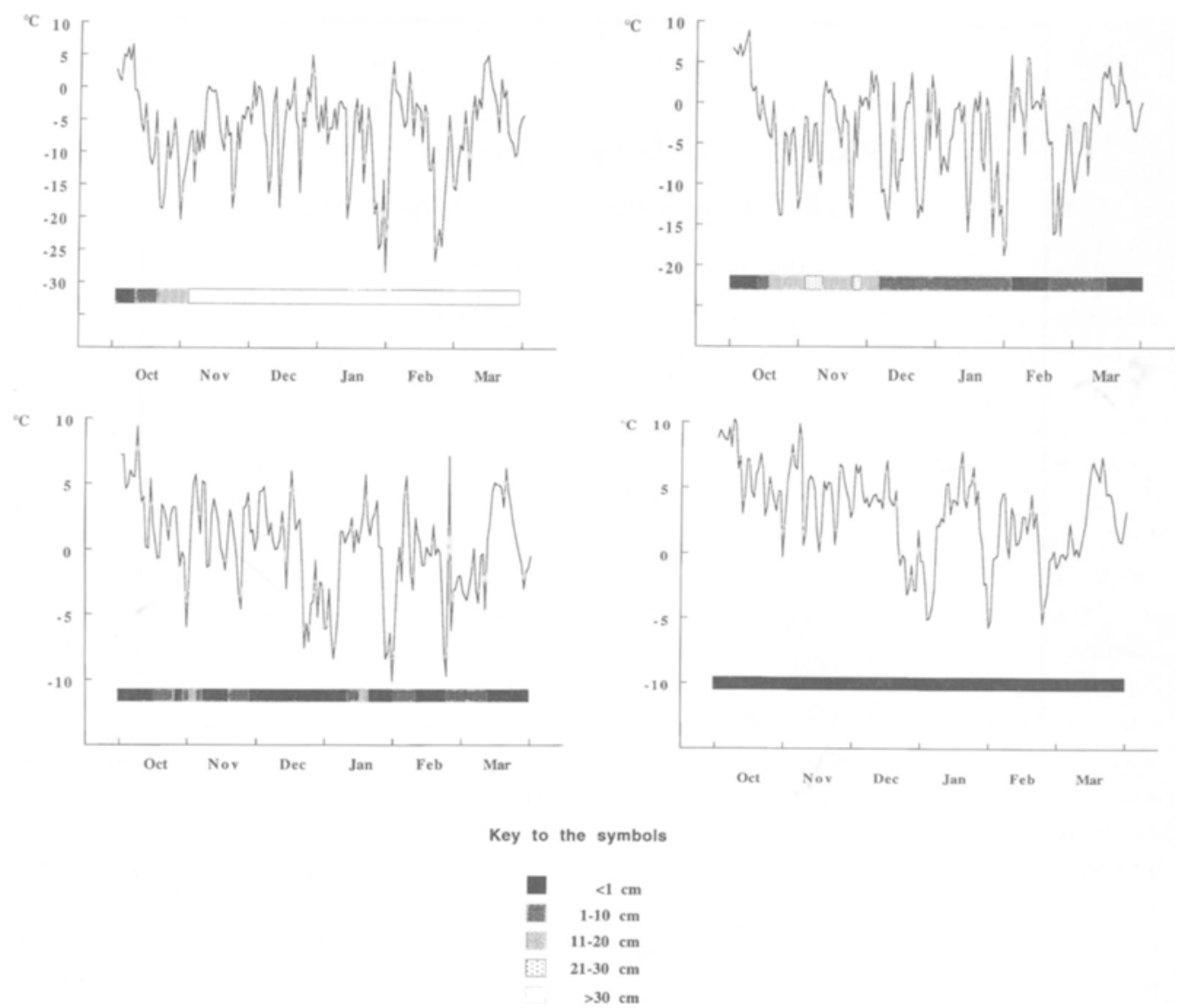

Figure 3. The daily mean temperatures and the depth of snow of region 9 (a), region 8 (b), region 5 (c) and region 1 (d) from October 1st to March 31st.

cluded that if there is a large increase in the rate of excretion of oocysts of E. alabamensis by calves 8 to 10 days after they have been turned out to pastures previously grazed by calves, these oocysts must originate from sporulated oocysts already present on the pasture.

It has been shown that Eimeria oocysts can survive temperatures of -5 to $-8^{\circ} \mathrm{C}$ for several months (Wilson \& Morley 1933, Marquardt et al. 1960, Francalanci 1968), but their resis- tance to temperatures of between -19 and $-30^{\circ} \mathrm{C}$ is more limited; at $-30^{\circ} \mathrm{C}, 37 \%$ of oocysts of E. zuernii survived for $6 \mathrm{~h}$, and only $5 \%$ survived for 24h (Marquardt et al. 1960); oocysts of E. arloingi, E. ninakohlyakimovae and $E$. parva which had been conditioned at $-19^{\circ} \mathrm{C}$ for $24 \mathrm{~h}$, survived for $24 \mathrm{~h}$ at $-30^{\circ} \mathrm{C}$, and 19 to $43 \%$ were viable after 14 days at $-25^{\circ} \mathrm{C}$ (Landers 1953). In Sweden, the temperature in winter often falls below $-5^{\circ} \mathrm{C}$, but during long spells of very cold weather the ground is 
often protected by an insulating layer of snow. The present study was designed to investigate whether oocysts of E. alabamensis can survive on pasture and cause clinical coccidiosis under different climatic conditions.

\section{Materials and methods}

The investigation consisted of 2 parts - a questionnaire study (Study A) and a fecal sample study (Study B), and was carried out in 9 regions of Sweden (Fig. 1). Each region corresponded with the area covered by a regional artificial insemination (AI) cooperative. Between them the regions represented all but the alpine zone and zone VIII of the climatic zones indicated on the map published by the Swedish Society for Horticulture (Fig. 1). The alpine zone and zone VIII were excluded, because no cattle are reared there. In addition, zones I and IV were each divided into 2 subzones ( $a$ and $b$ ) because of differences between them in average winter temperature and snow cover.

The 9 regional AI cooperatives were selected among those cooperatives which covered an area that was limited to only 1 of the climatic zones. One cooperative was selected at random for each of the zones Ia, Ib, II, III, IVa, $\mathrm{IVb}$ and VII, but for the zones V and VI, 2 regional cooperatives, which each covered areas within both zones, were used.

\section{Study $A$}

Fifty dairy farmers were selected at random among the members of each of the 9 AI cooperatives. In April 1993 a letter and a questionnaire were sent to the 450 farmers. The letter described the background and purpose of the investigations and invited those farmers who had used the same pasture for their first-season grazing calves for at least 5 years and who intended to use it again in 1993 to take part in
Study B. The 450 farmers were asked to complete the questionnaire. It was designed to gather information about the farmers' use of their pastures for young cattle and about the incidence of diarrhoea during the animals' first 2 weeks on pasture (Fig. 2).

\section{Study B}

Study B was carried out between May and July 1993 on 59 dairy farms. Eight of these were in region 1, 6 in region 2,9 in region 3,11 in region 4,6 in region 5,7 in region 6,2 in region 7,8 in region 8 , and 2 in region 9 . The mean ( $\pm 95 \%$ confidence interval) number of cows per herd was $33.5 \pm 6$. There were no significant differences between the mean numbers of cows in the herds in the 9 regions.

Information on the weather conditions from October 1992 to March 1992 in each of the 9 regions was obtained from the Swedish Meteorological and Hydrological Institute, Norrköping. The coldest weather occurred in region 9 (Fig. 3a) where the minimum temperature was $-36.5^{\circ} \mathrm{C}$. However, after October $28 \mathrm{th}$, this region was covered by a layer of snow more than $30 \mathrm{~cm}$ thick. In region 8 (Fig. $3 \mathrm{~b}$ ), the snow was more than $20 \mathrm{~cm}$ thick for only approximately 7 days, and after December 4th, although temperatures below $-10^{\circ} \mathrm{C}$ were recorded on several occasions, the snow cover did not exceed $10 \mathrm{~cm}$. In region 5 (Fig. $3 \mathrm{c})$, the depth of snow exceeded $10 \mathrm{~cm}$ for 10 days. Subzero temperatures were recorded on 75 days between October and March, and the minimum temperature was $-15.6^{\circ} \mathrm{C}$. Region 1 (Fig. 3d) had the mildest weather; the mean temperature fell below $0^{\circ} \mathrm{C}$ for only 37 days, the minimum temperature was $-8.6^{\circ} \mathrm{C}$, and there was virtually no snow. The other regions experienced intermediate weather conditions. At the end of the housing period, the calves on the 59 farms were either kept in pens which were bedded with straw or wood-shavings (12 
herds) or had slatted floors (20 herds), or they were kept tethered ( 27 herds). They were turned out in April on 2 farms, in May on 34 farms, in June on 18 farms and in July on 5 farms. The farms on which the calves were turned out during April or the first 2 weeks of May were all in southern Sweden (regions 1 to 6 ), but some of the farms in these regions turned their calves out in late June and July. The numbers of calves turned out to pastures ranged from 4 to 54 (mean $\pm 95 \%$ confidence interval is $10.2 \pm 2.1$ ), and the age of the animals at turnout ranged from 2 to 21 months. None of the animals had previously been on grass.

The pastures used for the calves had previously been grazed by first-season grazing cattle for between 5 and 40 (mean 14.3) years. Thirtythree of the farmers had allowed older cattle or horses to graze their calf pastures in previous years, and 11 had used the pastures for older cattle, and 1 for horses earlier in the spring 1993.

Samplings and parasitological examinations. Sets of 5 samples of faeces were collected from the farms on 4 occasions: first, from the floor of the calf-house within the last 2 weeks before the calves were turned out, and then 3 times from the pasture on days 4-5 and 8-9 and 10-11 after turning out. The samples were taken from the 5 freshest pats available on each occasion. However, on 3 farms, only 4 samples were collected before turning out and, on 2 farms, fecal samples were only collected twice at pasture. The material therefore consisted of 292 samples collected before the calves were turned out, and 875 samples collected from the pasture. The sets of samples were collected by the farmers and sent to the Experimental Station within 14 days after they had been collected. Samples which were not sent to the laboratory on the day of collec- tion were kept in a cool place until forwarding.

The number of oocysts per $g$ of feces (opg) was counted by a modified McMaster technique, and the species of the coccidia were identified on basis of the morphology of the unsporulated oocysts viewed under a light microscope (Anon. 1986).

The overwintering of oocysts of E. alabamensis on the pasture was investigated only on the 48 farms where the first-season grazing calves had been turned out to pastures, which had not been grazed by any cattle since the previous autumn. Oocysts were considered to have overwintered on the pasture, if a substantial increase in the excretion rate of oocysts of $E$. alabamensis could be demonstrated 8 to 11 days after the calves had been turned out. This criterion was considered fulfilled if the mean opg in a set of samples collected either 8-9 or 10-11 days after turnout exceeded the mean by at least 50000 opg in each of the 2 sets of samples collected earlier, and if at least 1 of the samples in the set contained more than 100000 opg.

The consistency of each fecal sample was scored subjectively on a scale from 1 to 5 . A score of 1 indicated firm feces, 3 porridge-like feces, and 5 watery feces. If the feces in a sample had a score of $3 / 4,4,4 / 5$, or 5 , it was considered to be diarrhoeic.

\section{Statistical analysis}

Before analysis, the estimated incidence of diarrhoea on each farm during the calves' first 2 weeks on pasture was graded on a scale from 0 to 2 , with 0 indicating that diarrhoea either did not occur or occurred very rarely, 1 that diarrhoea seldom occurred, and 2 that it frequently occurred. The difference between the incidence of diarrhoea suffered by herds which grazed pastures that had been used for at least 5 successive years, and the incidence 
in herds which grazed pastures which had not been used for such a long period was evaluated by using Mann-Whitney U statistics. This statistical test was used also to analyse the difference between the fecal consistency in calves from herds in which all faeces samples collected on days 8 to 11 contained less than $850000 \mathrm{opg}$, and the fecal consistency in calves from herds in which 1 or more samples contained more than 850000 opg. All other statistical analyses were made by the Kruskal-Wallis test, with pairwise comparisons using Mann-Whitney U statistics (Altman 1991).

\section{Results}

Study $A$

Of the 450 farmers, 321 (71\%) completed the questionnaires in a way that allowed them to be evaluated adequately. (However, 2 farmers did not answer question 2 (Fig. 2.)) Nineteen $(6 \%)$ of these 321 farmers did not turn their young cattle out to grass, and $4(1 \%)$ of them turned their animals out into huge forested areas. Of the 298 farmers who turned their calves out on to traditional pastures, 179 $(60 \%)$ had used the same pasture for at least 5 successive years (Table 1). However, in region 7 , only $34 \%$ of the 32 farmers had used the same pasture for 5 years or more, whereas in region $4,87 \%$ of the 39 farmers had done so. The estimated incidence of diarrhoea among the calves during their first 2 weeks at pasture is shown in Table 2. Farmers who had used the same pasture for at least 5 years reported a significantly $(\mathrm{p}<0.001)$ higher incidence of diarrhoea than did farmers who used different pastures in different years. The incidence of diarrhoea in the subgroup of 59 herds selected to participate in Study B did not differ significantly from the incidence in the other 120 herds in Study A, in which the same pasture had been used for 5 or more years (Table 3).
Table 1. Previous use of present pasture for calves in 298 dairy herds.

\begin{tabular}{cc}
\hline No. of years & No. of herds \\
\hline $0-2$ & $45(15 \%)$ \\
$3-4$ & $74(25 \%)$ \\
$5-10$ & $89(30 \%)$ \\
$>10$ & $90(30 \%)$ \\
\hline
\end{tabular}

Table 2. Estimated incidence* of diarrhoea in calves from 296 dairy herds during their first 2 weeks on pasture.

\begin{tabular}{lcc}
\hline \multirow{2}{*}{ Incidence } & \multicolumn{2}{c}{ No. of herds } \\
& \multicolumn{2}{c}{ Same pasture used for calves for } \\
\cline { 2 - 3 } & $<5$ years & $>5$ years \\
\hline Very low & $64(55 \%)$ & $63(35 \%)$ \\
Low & $52(44 \%)$ & $106(59 \%)$ \\
Moderate to high & $1(1 \%)$ & $10(6 \%)$ \\
\hline
\end{tabular}

* Based on data from the questionnaire (Fig. 2).

Table 3. Estimated incidence* of diarrhoea in calves during their first 2 weeks on pasture in 179 dairy herds where the same pastures have been used for the calves for at least 5 years.

\begin{tabular}{lcc}
\hline Incidence & $\begin{array}{c}\text { Herds included in } \\
\text { Study B }\end{array}$ & $\begin{array}{c}\text { Herds not included in } \\
\text { Study B }\end{array}$ \\
\hline $\begin{array}{l}\text { Very low } \\
\text { Low }\end{array}$ & $17(29 \%)$ & $46(38 \%)$ \\
$\begin{array}{l}\text { Moderate } \\
\text { to high }\end{array}$ & $38(64 \%)$ & $68(57 \%)$ \\
Total & $4 \quad(7 \%)$ & $6 \quad(5 \%)$ \\
\hline
\end{tabular}

* Based on data from the questionnaire (Fig. 2).

\section{Study $B$}

In the fecal samples collected from the floors of the calf-houses, 12 species of Eimeria were identified: $E$. bovis occurred in $34 \%$ of the samples, E. ellipsoidalis in $21 \%$, and E. alabamensis in $16 \%$. The other species, in order of decreasing frequency of isolation, were: $E$. 
wyomingensis, E. canadensis, E. auburnensis, E. subspherica, E. zuernii, E. cylindrica, E. bukidnonensis, E. brasiliensis, and E. pellita. In most cases, the numbers of oocysts were small: $48 \%$ of the samples contained no oocysts, $32 \%$ contained $100-500 \mathrm{opg}$, and only $5 \%$ contained more than 2100 opg. The highest count was 94000 opg, of which 84000 were E. subspherica. Less than 500 opg of E. alabamensis were found in $95 \%$ of the samples, and the number exceeded 1500 opg in only $1 \%$ of the samples. The highest number of oocysts of E. alabamensis found before turnout was 32000 opg.

In the samples taken from the pasture 11 of the above mentioned species of Eimeria were found - all except $E$. pellita. The sets of samples collected 4 to 5 days after turnout differed little from what was seen in samples from the calf-house: $65 \%$ of the 290 samples were positive for Eimeria oocysts, and the highest count recorded was 19200 opg, all of which were $E$. subsperica. Oocysts of $E$. bovis were found in $44 \%$ of the samples, and E. ellipsoidalis and E. alabamensis occurred in $26 \%$ and $28 \%$, respectively, of the samples. The highest number of oocysts of E. alabamensis found was 12100 opg.

In the 585 samples collected between 8 and 11 days after turnout, E. alabamensis was the dominant species and occurred in $77 \%$ of the samples. The numbers of oocysts of E. alabamensis were significantly $(\mathrm{p}<0.05)$ higher in these samples, as compared to samples collected earlier, in 44 of the 59 herds. E. bovis occurred in $26 \%$ of the samples, and E. ellipsoidalis in $14 \%$. Fewer than 500 opg of $E$. alabamensis were found in only $30 \%$ of the samples, more than 1500 were found in $61 \%$, more than 50000 in $29 \%$ and more than 850000 in $6 \%$. The largest number of oocysts of $E$. alabamensis found was 28.56 million opg. In contrast, the numbers of oocysts of other species were low. In $95 \%$ of the samples there were less than 500 opg of E. bovis, and less than 300 opg of E. ellipsoidalis and $E$. zuernii. The highest counts of E. bovis, E. ellipsoidalis and E. zuernii were 20000, 21000 and 38000 , respectively.

Overwintering of oocysts of E. alabamensis was demonstrated on $27(56 \%)$ of the farms representing all of the 9 regions. Of the 27 farms, 3 had not turned their calves out until July. In one of these, all 5 fecal samples collected 10 days after the calves were turned out, contained more than 1.5 million opg of $E$. alabamensis.

On 20 (34\%) of the 59 farms, the number of oocysts in 1 or more samples exceeded 850000 opg. This was comparable with the numbers observed in animals with clinical coccidiosis due to E. alabamensis. The 20 farms represented all of the 9 climatic zones. The fecal samples collected from these herds 8 to 9 days after turnout were significantly $(\mathrm{p}<0.001)$ softer (median score 3 ) than the feces in comparable samples from the other 39 herds (median score 2). In 6 herds, the fecal samples with more than 850000 opg were diarrhoeic in consistency.

The calves kept in pens with bedding excreted significantly $(\mathrm{p}=0.001)$ more oocysts of $E$. alabamensis 8 to 11 days after being turned out than did the calves kept in pens with slatted floors, and these calves excreted significantly $(p=0.02)$ more oocysts than the calves which had been tethered.

Calves turned out to pastures grazed by older cattle or horses in previous years, as well as the calves turned out to pastures grazed by older cattle or horses earlier in the spring 1993, excreted significantly $(\mathrm{p}<0.001)$ fewer oocysts of $E$. alabamensis than the calves which were turned out on to pastures that had been used only for first-season grazing cattle. 


\section{Discussion}

The 59 farmers who participated in Study B (as well as in Study A) all volunteered their herds for the study. As a result, it might have been expected that a higher than average proportion of them would have previously had problems with diarrhoea. However, as can be seen from Table 3, the frequency of diarrhoea among these 59 herds was similar to that among the other 120 herds in Study A, which had also used the same pasture for 5 or more years. Furthermore, the geographical distribution of the 59 experimental herds corresponded well with the distribution of dairy herds throughout Sweden, and they can therefore be considered to be representative of all the dairy herds using old pastures.

The observed incidence of diarrhoea was significantly higher on the farms where the same pasture had been used for calves for 5 or more years than on the farms where different pastures had been used (Table 2). This result suggests that an infectious agent which had overwintered on the pasture was responsible for some of these outbreaks of diarrhoea. The significantly softer consistency of the fecal samples on the farms where more than 850000 opg of $E$. alabamensis were found, strongly suggests that this agent was E. alabamensis. Individual fecal samples from $34 \%$ of the farms in the study contained oocysts in numbers comparable with those found in calves with clinical coccidiosis due to E. alabamensis. Considering that about $60 \%$ of the farms were using old pastures, and assuming that this figure is representative of farms throughout Sweden, first-season grazing calves on nearly $20 \%$ of the Swedish dairy farms could be at risk of developing coccidiosis due to E. alabamensis. A precise measure of the herd incidence of the disease cannot be calculated from the results of the present study. Due to practical and economical reasons, the samplings were carried out by the volunteering farmers, and to ensure a reasonably high number of participating farms a simple procedure had to be chosen. It was therefore not considered possible to sample the same individual calves on each sampling occasion. In the present study, the herd incidence therefore should be based only on samples collected during the period when large numbers of oocysts were being excreted 8 to 11 days after turnout. However, this is likely to underestimate the true incidence, because as indicated by previous studies of calves infected either experimentally (Hooshmand-Rad et al. 1994) or naturally (Svensson et al. 1994) with E. alabamensis, diarrhoea often develops before the onset of oocyst excretion. The incidence may also be underestimated due to difficulties in collecting faeces of very loose consistency from the ground. However, because diarrhoeic fecal samples containing more than 850000 opg were found in 6 $(10 \%)$ of the 59 herds, it is reasonable to conclude that the herd incidence of clinical coccidiosis due to E. alabamensis in first-season grazing cattle in Sweden is at least $6 \%$.

In some cases under all the climatic conditions studied, the oocysts of $E$. alabamensis were shown to have overwintered on the pasture, and were excreted in numbers comparable with those recorded in calves with clinical coccidiosis due to E. alabamensis. After a winter like that of $1992 / 93$, any calf in the country turned out on to a permanent pasture would therefore be at risk of contracting coccidiosis due to E. alabamensis. The winter of 1992/93, like the preceeding 4 winters, was unusually mild. Although the temperatures in October and November were up to $7^{\circ} \mathrm{C}$ below normal, during the period from December to March they were between 1 and $6^{\circ} \mathrm{C}$ above normal. However, even during a normal winter, temperatures lower than those recorded in region 9 (Fig. 3a) rarely occur in zones I-V (Fig. 1), 
where up to $90 \%$ of the cattle population in Sweden are kept. As a result, it is likely that even during a normally cold winter, the risk of coccidiosis due to E. alabamensis is a reality on most Swedish farms using old pastures for the first-season grazing calves.

It has been shown that oocysts of Eimeria species can survive the winter in other countries with a climate like that of Sweden. For example, Helle (1970) found that in a region of Norway with permanent snow cover and sub-zero temperatures from December to March, lambs turned out to permanent spring pastures had significantly higher fecal oocyst counts and a higher incidence of diarrhoea than lambs turned out on to new pastures. Furthermore, Utebaeva \& Svanbaev (1977) found that after storing oocysts of avian Eimeria species (E. tenella, E. necatrix and E. mitis) on the surface of the ground, or buried 5 or 20 $\mathrm{cm}$ below ground throughout the winter in different regions of Kazakhstan, the sporulated oocysts were infective to chicks in the spring. However, the unsporulated oocysts did not overwinter in the region with the lowest mean temperatures: $-7^{\circ} \mathrm{C}$ in December and $-21^{\circ} \mathrm{C}$ in January.

In 3 of the experimental herds, the calves became infected with overwintered oocysts as late as July, and in 1 of them, all 5 samples collected 10 days after the calves were turned out, contained more than 1.5 million opg of $E$. alabamensis. This result corresponds to those of an unpublished study by the author in which it was shown that overwintered oocysts of E. alabamensis on the pasture caused clinical coccidiosis in calves turned out in the last week of June. Delaying the turnout of calves is thus unlikely to be an adequate method for preventing coccidiosis due to E. alabamensis in calves turned out to heavily contaminated pastures.

The calves which were turned out to pastures that had previously been used by older cattle and horses excreted significantly fewer oocysts of E. alabamensis than the calves which were turned out to pastures that had been grazed only by first-season grazing calves. This result suggests that the older cattle or horses may have reduced the contamination of the pasture with oocysts because, owing to their immunity (or low susceptibility to infection), they excreted relatively few new oocysts after becoming infected (or having ingested oocysts). In an unpublished study, the author has shown that cattle which suffered clinical coccidiosis due to E. alabamensis during their first grazing season excreted very few oocysts when they were turned out to a heavily contaminated pasture the following spring. Similarly, older more resistant animals have been shown to have a "diluting" effect on the herbage infectivity of trichostrongyle larvae (Downer \& Fallon 1973, Nansen et al. 1990), and alternate grazing with other host species, such as sheep, is known to reduce the load of helminths for cattle and other hosts (Morley \& Donald 1980). To graze older cattle, sheep or horses on contaminated pastures might therefore be an effective strategy for reducing the problems of coccidiosis due to E. alabamensis in calves.

The finding that the calves which, during the winter, were kept in pens with bedding excreted more oocysts 8 to 11 days after they were turned out than the calves which had been kept in pens with slatted floors is in contrast to previous results. In an unpublished study, the author has found that when calves which had been kept in pens with slatted floors were turned out to a contaminated pasture, they developed coccidiosis due to $E$. alabamensis, and excreted oocysts of this species in millions per gram of faeces. Younger calves from the same herd which had been kept in pens bedded with straw remained clin- 
ically unaffected and excreted only up to $300000 \mathrm{opg}$ of E. alabamensis when they were turned out to a similar pasture. It was suspected that the calves in the pens bedded with straw had become more heavily infected with oocysts of E. alabamensis during the winter and had developed immunity against the organism before they were turned out. The difference between the results of the 2 studies indicate the need for further investigations of the mechanism of the development of immunity to E. alabamensis.

The results of this study provide further evidence that $E$. alabamensis is an important cause of diarrhoea in young Swedish cattle shortly after they are turned out to pasture. Furthermore they show that coccidiosis due to E. alabamensis could occur anywhere in the country.

\section{Acknowledgements}

The study was financially supported by Agria Insurances Inc. and the Swedish Farmer's Foundation for Agricultural Research. Dr. Jon Bergström, Dr. Bo Pehrson and Prof. Arvid Uggla are acknowledged for their help in planning the study. Thanks are also due to Jan Nordblom, Irina Nyberg, Helena Olofsson and Inger Ström for laboratory work and to the participating farmers for their interest and most valuable assistance.

\section{References}

Altman DG: Practical Statistics for Medical Research. Chapman and Hall, London, 1991, pp. 213-215.

Anonymous: Manual of Veterinary Parasitological Laboratory Techniques. Reference Handbook 418, 3rd ed, Ministry of Agriculture, Fisheries and Food (UK), 1986, pp. 11-12.

Davis LR, Boughton, DC, Bowman GW: Biology and pathogenicity of Eimeria alabamensis Christensen, 1941: An intranuclear coccidium of cattle. Amer. J. vet. Res. 1955, 16, 274-281.

Downer NE, Fallon R: Intensive calf grazing: management systems for fewer worms and better gains. Farm. Food Res. 1973, 4, 102-105.

Francalanci $G$ : Effect of low temperature on sporulation and survival of the oocysts of Eimeria perforans, media, magna and irresidua. Nuova Vet. 1968, 44, 256-263 (Abstract in Vet. Bull. 1969, 39: abstract no 1964).

Gräfner G, Graubmann H-D, Kron A, Müller H, Daetz H-H, Plötner J, Benda A: Zum Auftreten der Weidekokzidiose in Jungrinderbeständen. (Occurrence of grass coccidiosis among young cattle.) Mh. Vet.-Med. 1982, 37, 776-779.

Gräfner G, Graubmann, H-D, Daetz H, Müller H, Menke N: Zur Epizootiologie der Eimeria alabamensis-Kokzidiose bei Jungrindern. (Epizootiology of Eimeria alabamensis coccidiosis in young cattle.) Mh.Vet.-Med. 1985, 40, 44-47.

Helle $O$ : Winter resistant oocysts in the pasture as a source of coccidial infection in lambs. Acta vet. scand. 1970, 11, 545-564.

Hooshmand-Rad P, Svensson C, Uggla A: Experimental Eimeria alabamensis infection in calves. Vet. Parasitol. 1994, 53, 23-32.

Landers EJ: The effect of low temperatures upon the viability of unsporulated oocysts of ovine coccidia. J. Parasitol. 1953, 39, 547-552.

Levine ND: Veterinary Protozoology. Iowa State University Press, London 1985, p. 142.

Marquardt WC, Senger CM, Seghetti L: The effect of physical and chemical agents on the oocysts of Eimeria zuernii. J. Protozool. 1960, 7, 186-189.

Morley FHW, Donald AD: Farm management and systems of helminth control. Vet. Parasitol. 1980, 6, 105-134.

Nansen P, Steffan P, Monrad J, Gronvold J, Henriksen SAa: Effects of separate and mixed grazing on trichostrongylosis in first- and secondseason grazing calves. Vet. Parasitol. 1990, 36, 265-276.

Soekardono S, Ernst JV, Benz GW: The prepatent and patent periods of Eimeria alabamensis and further description of the exogenous stages. Vet. Parasitol. 1975, 1, 19-33.

Svensson C, Uggla A, Pehrson B: Eimeria alabamensis infection as a cause of diarrhoea in calves at pasture. Vet. Parasitol. 1994, 53, 33-43.

Utabaeva MK, Svanbaev $S K$ : Materialy po koktzidijam kur v kazakhstanje. (Data on chicken coccidia in Kazakhstan). Trudy Inst. Zool. Akad. nauk Kazakh. SSR 1977, 37, 33-45.

Wilson ID, Morley LC: A study of bovine coccidiosis, II. J. Amer. vet. med. Assoc. 1933, 82, 826850. 


\section{Sammanfattning \\ Överlevnad av Eimeria alabamensis-oocystor på bete under olika klimatförhållanden i Sverige.}

Förmågan hos oocystor av koccidiearten Eimeria alabamensis att övervintra på betesmarker och orsaka klinisk koccidios i olika delar av Sverige undersöktes under maj till juli 1993 genom insamling av träckprover från kalvar från 59 gårdar, på vilka samma betesmark hade använts för förstagångsbetande kalvar under minst 5 år. Gårdarna var belägna i 9 olika regioner av landet med olika klimatförhållanden under vintern. På varje gård insamlades träckprover från kalvarna vid 4 olika tillfällen: från stallgolvet en gång före betessläppning och från betesmarken på dag 4 eller 5,8 eller 9 och 10 eller 11 efter betessläppning. E. alabamensis-oocystor ansågs ha övervintrat på betesmarken om en kraftig ökning av utskiljningen av oocystor av denna art kunde påvisas hos kalvar 8 till 11 dagar efter att de släppts ut på betesmark som ej använts av nötkreatur sedan föregående år. Övervintring påvisades på 27 gårdar och i alla de 9 regionerna. Träckprover innehållande mer än 850000 oocystor per gram träck, dvs ett antal motsvarande det som ses hos kalvar med klinisk E. alabamensis-koccidios, insamlades från 20 gårdar (34\%), vilka representerade samtliga undersökta klimatzoner. En senareläggning av betessläppningen till början av juli påverkade inte infektionsgraden hos kalvarna. De kalvar som släpptes ut på betesmarker som betats av äldre nötkreatur eller hästar, antingen tidigare under våren eller under tidigare år, utskiljde dock signifikant färre oocystor än kalvar som släpptes ut på betesfållor som tidigare endast använts för förstagångsbetare. En enkätundersökning besvarad av 321 mjölkproducenter avslöjade att $179(60 \%)$ av de 298 djurägare som släppte ut sina kalvar på traditionella betesmarker hade använt samma hage för sina förstagångsbetare under minst 5 år. Dessa djurägare upplevde sig ha en signifikant högre incidens av tidiga betesdiarréer hos sina kalvar än djurägare som ofta bytte betesmark.

(Received February 25, 1994; accepted September 8, 1994).

Reprints may be requested from: C. Svensson, Experimental Station, Veterinary Institute, P.O. Box 234, S-532 23 Skara, Sweden. 